DOI: $\square$ https://doi.org/10.15407/techned2020.04.019

\title{
ELECTROMAGNETIC PROCESSES IN A FLAT CIRCULAR SYSTEM WITH AN INDUCTOR BETWEEN THIN BIFILAR COILS
}

Journal

Publisher

ISSN

Issue

Pages
Tekhnichna elektrodynamika

Institute of Electrodynamics National Academy of Science of Ukraine 1607-7970 (print), 2218-1903 (online)

No 4, 2020 (July/August)

$19-24$

\author{
Authors \\ Yu.V. Batygin ${ }^{\star}$, S.O. Shinderuk ${ }^{\star *}$, E.O. Chaplygin ${ }^{\star \star \star}$, O.F. Yeryomina ${ }^{\star \star \star *}$ \\ Kharkiv National Automobile and Highway University, \\ 25, Yaroslava Mudruho Street, Kharkiv, 61002, Ukraine, \\ e-mail: s.shinderuk.2016102@ukr.net \\ * ORCID ID : https://orcid.org/0000-0002-1278-5621 \\ ** ORCID ID : https://orcid.org/0000-0002-6354-4174 \\ *** ORCID ID : https://orcid.org/0000-0003-1448-6091 \\ **** ORCID ID : https://orcid.org/0000-0002-8123-1104
}

\section{Abstract}

The analysis of electromagnetic processes occurring in the inductor system with a bifilar coil as well the numerical estimates of the characteristics of the excited currents under conditions of high intensity of penetration of the acting fields is conducted. In order to study electromagnetic processes in thin-walled windings of a bifilar, in contrast to their massive implementations, where there is an energy intense output into the surrounding space, a strict mathematical approach with application of the theory methods of electric-magnetic field is used. The numerical estimates are conducted with help of the obtained analytical dependences. It was shown that the amplitude of the current induced in the bifilar windings of the experimental model of the considered inductor system in the ratio to the exciting current does not exceed $10-15 \%$, which is significantly less than the possible maximum of $\sim 50 \%$. It is noted that the radial distribution of the induced current, in contrast to the uniform distribution of the exciting current in the inductor, has an increasing character from the inner to the outer radius of the bifilar winding. The obtained results allow to assess the level of efficiency when choosing design solutions for the new elements of the equipment in the magnetic-pulsed metal processing. References 11 , 
figures 3 .

Key words: bifilar coil, flat circular inductor system, magnetic-pulse treatment of metals, energy transformation, solenoid-inductor.

Received: 17.01 .2020

Accepted: 06.05.2020

Published: 26.06.2020

\section{References}

1. Padmanabhan K., Swaminathan P. Electronic Components. New Delhi: Laxmi Publications LTD, 2006. 204 p.

2. Shneerson G.A., Dolotenko M.I., Krivosheev S.I. Strong and Superstrong Pulsed Magnetic Fields Generation. Berlin: Walter de Gruyter, 2014. 429 p. DOI: https://doi.org/10.1515/978311 0252576

3. Batygin Yu., Barbashova M., Sabokar O. Electromagnetic Metal Forming for Advanced Processing Technologies. Cham: Springer International Publishing AG, 2018. 94 p. DOI: https: //doi.org/10.1007/978-3-319-74570-1

4. Batyhin Y.V., Hnatov A.V. The features of the electrical magnetic forces excitation in the magnetic pulse sheet ferromagnetic metal working. Tekhnichna Elektrodynamika. 2012. No 1. Pp. 71-77. (Ukr)

5. Hnatov A., Arhun Shch., Ponikarovska S. Energy saving technologies for urban bus transport. International Journal of Automotive and Mechanical Engineering. 2017. Vol. 14. No 4. Pp. 4649-4664.

https://doi.org/10.15282/ijame.14.4.2017.5.0366

6. Batyhin Y.V., Havrilova T.V., Shinderuk S.A., Chaplyhin Ye.A., Saenko V.A. Flat inductor system with massive bifilar coils. Analysis of electromagnetic processes. Tekhnichna inzheneriia . 2019. Vol. 84. No 2. Pp. 115-119. (Rus)

7. Shim J.-Y., Kang B.Y., Park D.-H., Kim I.S. A Fundamental Study on Magnetic Pulse Forming with Bar Forming Coil. Korean Society of Manufacturing Technology Engineers. 2011. Vol. 20. No 3. Pp. 292-297.

8. Inanan G., Baranoglu B., Aydin E. An Application of High-Power Electromagnetic Pulse: Forming of sheet metal using electromagnetic waves. Proc. 9th International Conference on Electrical and Electronics Engineering (ELECO), November 2015, Bursa, Turkey. Pp. 284-288. 
DOI:

https://doi.org/10.1109/ELECO.2015.7394594

9. Psyk V., Rich D., Kinsley B.I., Tekkaya A.E., Kleiner M. Electromagnetic Forming - A Review. Journal of Material Processing Technology. 2011. No 211. Pp. 787-829. DOI: https://d oi.org/10.1016/j.jmatprotec.2010.12.012

10. Korn H., Korn T. Mathematical Handbook. Moskva: Nauka, 1973. 831 p. (Rus)

11. Yavorskii B.M., Detlaf A.A., Lebedev A.K. Physics handbook for engineers and students of universities. Moskva: Oniks Publishing, 2006. 1056 p. (Rus)

PDF

This work is licensed under a Creative Commons Attribution-NonCommercial-NoDerivatives $\underline{4.0}$ International License 